\title{
Article \\ CEO Compensation in Korea: Is It Different than in the US? A Comparison between Korean Non-Life Insurance Firms and US Property-Liability Insurance Firms
}

\author{
Sangyong Han * and Hyejeong Mun \\ Korea Insurance Research Institute (KIRI), 38 Gukjegeumyung-ro 6-gil, Youngdeungpo-gu, Seoul 07328, Korea; \\ hjmun@kiri.or.kr \\ * Correspondence: syhan@kiri.or.kr
}

Citation: Han, Sangyong, and Hyejeong Mun. 2021. CEO Compensation in Korea: Is It Different than in the US? A Comparison between Korean Non-Life Insurance Firms and US Property-Liability Insurance Firms. International Journal of Financial Studies 9: 61. https://doi.org/ 10.3390/ijfs9040061

Academic Editors: Rob Hull and Sabri Boubaker

Received: 10 September 2021 Accepted: 1 November 2021 Published: 3 November 2021

Publisher's Note: MDPI stays neutral with regard to jurisdictional claims in published maps and institutional affiliations.

Copyright: (c) 2021 by the authors. Licensee MDPI, Basel, Switzerland. This article is an open access article distributed under the terms and conditions of the Creative Commons Attribution (CC BY) license (https:// creativecommons.org/licenses/by/ $4.0 /)$.

\begin{abstract}
This study investigates the level, structure, and pay-for-performance relationship of CEO compensation in Korean non-life insurance companies. We find that seniority plays an important role in setting CEO compensation practices and that performance-based pay, such as bonus, is more effective than base salary in enhancing shareholder value for Korean non-life insurers. Unlike previous studies that show that international differences in executive pay have been diminished considerably since the 2000s, our evidence shows that there is a remarkable difference in CEO compensation between Korean non-life insurers and U.S. property-liability insurers. Furthermore, we provide evidence that the pay-performance relationship is weaker in Korean non-life insurance companies relative to US counterparts, suggesting that it is necessary for Korean non-life insurers to tie performance-based compensation more closely to shareholder value in the design of CEO compensation.
\end{abstract}

Keywords: CEO compensation; pay-performance sensitivity; property-liability insurers

JEL Classification: G22; G39; J33

\section{Introduction}

The current low interest rate environments and adoption of new insurance accounting standard and solvency systems, such as IFRS 17 and K-ICS, ${ }^{1}$ have demanded that CEOs of Korean insurance firms make decisions with a long-term perspective to survive and prosper under uncertain circumstances. The main purpose of executive pay is to motivate executives to exert their best efforts to enhance a value of a firm. The literature has found that managerial compensation schemes could alleviate agency problems by aligning the interest of the managers with that of shareholders (e.g., Jensen and Meckling 1976; Holmström 1979; Jensen and Murphy 1990). Therefore, the properly structured executive pay scheme can play a crucial role in the survival and long-term growth of Korean insurance companies. In this vein, Korean regulator, the Financial Supervisory Commission (FSC), has implemented a set of regulations on executive compensation, such as the establishment of a compensation committee and detailed requirements for executive remuneration disclosure in an effort to improve corporate governance and transparency of insurance companies.

Although insurance literature has typically focused on the US executive pay system where there is a long history of public disclosure on executive compensation (e.g., Mayers and Smith 1990; Eckles et al. 2011; Ma and Wang 2014), there have been very few studies of CEO compensation in non-US insurance firms, especially in Asian countries, due to a lack of data availability. Given that Korea has become an emerging power in the global insurance sector, ranked seventh in terms of total premium volume, an examination of executive compensation in Korea may be of interest from the perspective of both academics and practitioners alike. In this study, we examine executive pay schemes of Korean insurance 
companies by exploring the determinants of CEO compensation and pay-performance relationship in the Korean non-life insurance industry. Furthermore, we perform a comparison of CEO compensation schemes between Korean non-life insurers and U.S. property-liability insurers to investigate how CEO pay structure in Korean non-life insurance firms is different from that in their US counterparts. According to extant literature (e.g., Fernandes et al. 2013), most countries have adopted US-style compensation schemes due to an increased competition in the global market for capital, customers, and managerial talent. Thus, we examine whether CEO compensation in Korean non-life insurers is similar to US-style executive compensation, which is a current global trend or not.

Our sample includes publicly traded Korean non-life insurance companies over the period 2013-2018. In particular, we utilize the data on the detailed individual disclosure of CEO pay for Korean non-life insurers. By way of preview, we find that seniority plays an important role in setting CEO's base salary in Korean non-life insurance firms and that firm performance is positively related to performance-based compensation, such as bonuses. Our evidence also shows that higher leverage and volatility of firm performance are associated with lower CEO compensation. With respect to pay-performance sensitivity, we demonstrate that performance-based pay is more effective than fixed-base salary in enhancing shareholder value in the design of CEO compensation in Korean non-life insurance firms. We also find that a proportion of performance-based pay in CEO compensation is consistently found to be positively related to firm performance, such as return on assets (ROA), return on equity (ROE), and Tobin's $Q$. For the comparison of CEO compensation between Korean non-life insurers and US property-liability insurers, our evidence shows that CEO compensation schemes in Korean non-life insurers are substantially different from those in US counterparts. Specifically, we provide evidence for a strong dominance of base salary in CEO compensation structure in Korean non-life insurance firms. We find that, on average, base salary consists of 56 percent of total CEO compensation for Korean non-life insurers, whereas base salary only accounts for 14 percent for U.S. property-liability insurers. With regard to performance-based compensation, annual bonuses account for 37 percent of total compensation and especially stock-based pay, including stock options and restricted stocks, has not been used in the CEO pay package of Korean non-life insurance companies. In contrast, incentive pay, such as bonuses, stock option awards, and restricted stocks, consists of more than 55 percent of total CEO compensation in US property-liability insurance firms. This substantial difference between two countries suggests that US property-liability insurance companies offer CEOs a more incentive-based compensation compared to Korean non-life insurance firms. Considering that international pay gap of executives has gradually become smaller since the mid-2000s, such a large pay differential is somewhat surprising.

To further investigate the differences in pay structure between Korean non-life insurers and U.S. property-liability insurers, we conduct a comparison of determinants of CEO compensation and pay-performance relationship. We find that relative to US counterparts, CEOs of Korean non-life insurers tend to receive higher bonus in firms that are larger and with higher line-of-business diversification and that they have greater CEO pay for taking the same level of risk. In addition, our evidence shows that the pay-performance relationship is weaker in Korean non-life insurance companies compared to their US property-liability counterparts. This result suggests that it is necessary for Korean non-life insurers to tie performance-based compensation more closely to shareholder value in the design of CEO compensation.

This study contributes to the literature in several ways. Our study provides new evidence on international executive compensation practices in the insurance industry. ${ }^{2}$ By providing direct evidence on $\mathrm{CEO}$ compensation from Korean non-life insurers and a comparison of Korean and US insurers' CEO pay, our study fills a gap in the literature that has so far typically focused on CEO compensation in the US insurance sector, thereby extending the research on executive pay to an international setting. Especially, our findings have an important implication for the debate over international pay differences. Prior studies have 
shown that as the disclosure of executive compensation increased globally after 2008-2009 financial crisis, international pay differences were substantially reduced (e.g., Basu et al. 2007; Conyon et al. 2011; Fernandes et al. 2013). However, our results suggest that this is not the case in CEO pay in Korean non-life insurance companies. Furthermore, our findings reveal that unlike US property-liability insurance firms, performance-based compensation has not been widely used in Korean non-life insurance companies, thus leading to a less tight relationship between CEO pay and shareholder wealth. Taken together, our study demonstrates unique features of executive compensation of Korean non-life insurance firms, which differs from the widely studied US executive pay system in many ways.

The remainder of the paper is structured as follows. Section 2 reviews the literature and describes the regulatory environment about executive compensation in Korea. Section 3 describes our data sources, sample selection, and empirical methodology. Section 4 provides variables that we use in our analyses. Section 5 presents the descriptive statistics and empirical results. Section 6 concludes the paper with the summary of our main findings.

\section{Background}

\subsection{Literature Review}

Executive compensation has received substantial attention from academics and practitioners alike, since it is considered as an effective way to alleviate agency problems by aligning the interest of managers with that of shareholders. Prior literature has found that CEOs whose personal wealth is closely linked to their firm's performance tend to take lower risks in order to protect their personal portfolio (e.g., Smith and Stulz 1985; Oldfield and Santomero 1997; Jensen et al. 2004). To address this problem, firms provide proper incentives for managers to bear more risk by offering them appropriate compensation (Holmström 1979; Holmström and Milgrom 1987; Kleffner and Doherty 1996). Darrough and Melumad (1995) state that providing CEOs with performance-based pay can mitigate adverse selection problems. Hall and Murphy (2002) find that risk-averse CEOs are more likely to require a risk premium for accepting the increased risk of equity-based pay. Stulz (1996) states that CEOs of a riskier firm tend to demand a higher risk premium.

The effect of managerial compensation on firm performance has been widely studied. Prior literature finds that CEO pay is positively associated with firm performance and that long-term incentives generated by equity-based pay are large compared to fixedbased salary. For instance, Murphy (1985) reports a positive relationship between firm performance and managerial compensation. Hall and Liebman (1998) contend that a positive relationship between managerial compensation and performance is the result of changes in the value of equity-based compensation, such as stock options and restricted stocks. Bertrand (2009) finds that CEO pay is positively associated with shareholder returns and firm profitability. Kuo et al. (2013) demonstrate that equity-based compensation results in greater firm performance. With respect to the determinants of CEO pay, Tosi et al. (2000) report that firm size and performance have a positive impact on total CEO compensation. Van Essen et al. (2015) provide evidence on the effect of managerial power on CEO pay by showing that when CEOs have power over the pay setting process, they tend to receive higher compensation, whereas when boards have more power than CEOs, CEOs are likely to get lower compensation. Blanes et al. (2020) find a positive association between CEO pay and firm performance, and they point out that firm size is the main driver of CEO compensation.

The literature has examined various topics relating to the level and structure of executive pay in an international setting (e.g., Jensen and Murphy 1990; Hall and Liebman 1998; Conyon and Murphy 2000; Craighead et al. 2004; Merhebi et al. 2006; Fernandes et al. 2013; Pan and Zhou 2018; de Andrés and Arranz-Aperte 2019). Prior studies have demonstrated that CEO pay in the US is much higher compared to that of foreign countries. The Towers Perrin (2006) survey reports that US CEOs earn approximately double the compensation of non-US CEOs. Bebchuk et al. (2002) point out that the CEO pay gap between US and foreign countries can be explained by the managerial power hypothesis 
that US CEOs have power to influence the board of directors, and therefore, set their own pay levels. Fernandes et al. (2013) investigate the difference in CEO compensation between the US and 13 developed countries. They reveal that international pay differentials have gradually decreased since the mid-2000s due mainly to increased competition in the global market for capital, customers, and managerial talent. Conyon et al. (2011) examine CEO pay difference between the US and the UK, and they report that US CEO pay premium decreases from 118 percent in 1997 to 23 percent in 2003. According to Willis Towers Watson Article (2020), UK, France, Germany, and Japan have increased the proportion of variable compensation over time, like the US executive compensation system. As of 2019, the median share of base salary was 10 percent in the US, 25 percent in the UK, 27 percent in Germany, 29 percent in France, and 40 percent in Japan. The remainder consists of annual bonus and long-term incentives, and the proportion of long-term incentives has risen steadily over the past five years. The change in Japan is particularly notable. In Japan, the portion of base salary (about 40-60 percent) is higher than that of other countries. However, since the introduction of the Japanese Corporate Governance Code in 2015, the proportion of performance-linked compensation has been increasing rapidly. For Japanese listed companies, variable compensation accounted for 42 percent of total compensation in 2013, but accounted for 60 percent in 2019.

A similar phenomenon is observed in China. Yang et al. (2021) investigate the executive remuneration data of 3668 Chinese listed companies from 1999 to 2017. They found that there was no consistent trend in the proportion of base salary and equity incentives before 2010. However, since 2010, the proportion of equity incentives has been consistently higher than that of base salary. From 2010 to 2017, the average share of base salary was 37 percent and that of equity incentives was 63 percent in Chinese public firms. Beck et al. (2020) provide evidence for executive compensation of German companies listed on the DAX or MDAX from 2006 to 2018. According to this study, German executives in 2018 earned more compensation in the variable compensation components than in 2006. In particular, the share of equity-based compensation increased from 15 percent in 2009 to 52 percent in 2018. This means that long-term incentives and equity-based compensation became more prevalent in Germany's executive compensation system, which has been affected by various regulations since the global financial crisis. In summary, prior studies suggest that non-US countries have been constructing an executive compensation system like the US by gradually increasing the proportion of performance-based compensation. However, Pan and Zhou (2018) mention that the CEO compensation structure in Japan is remarkably different from that of US firms by showing that Japanese firms' CEOs tend to get paid mostly by a fixed base salary (about two-thirds of total CEO compensation), which is not linked to their performance. They state that despite a global trend towards a US-style compensation model consisting of a high proportion of incentive compensation and low portion of fixed-based salary, this pattern does not apply to Japan.

\subsection{Regulatory Environment of Executive Compensation in Korea}

The regulations on executive compensation in Korea have experienced substantial changes over the last decade. After the global financial crisis in 2008-2009, most developed countries have improved disclosures in executive compensation practices in an effort to enhance corporate governance and transparency. To achieve this goal, the Financial stability board (FSB) established the Principles for Sound Compensation Practices and Implementation Standard (Principles and Standards, P\&S) in 2009 and encouraged countries of G-20 group members to observe the rules. Moreover, the increasing power of monitoring and discipline by foreign institutions pressured Korean public companies to disclose more detailed information on executive compensation. In response to an international trend and pressure from foreign investors, the Korean authority, the Financial Supervisory Commission (FSC), reformed regulation on executive pay. In 2013, FSC implemented a new regulation on better disclosures of executive compensation. The new regulation required Korean publicly traded companies to publicize information on individual CEO 
compensation. The information to be disclosed included not only the total amount of executive compensation but also the components of payment, such as salary, bonus, and stock-based compensation.

Prior to 2013, only the total amount of executive compensation was made public in a firm's business report, but individually named executive compensation was not disclosed. This made it hard for stakeholders to understand executive compensation practices and managerial incentive schemes in Korean public firms. The new regulation took effect in March 2013, under which all publicly listed Korean companies were required to report information on compensation paid to each of their executives so long as the registered executive's total remuneration was 500 million Won (approximately 500,000 in USD) or more. Under the new legislative framework in the disclosure of executive pay, the level and structure of executive compensation become public information. However, problems occurred when some companies deliberately changed their registered executives to unregistered ones to avoid this new regulation. To solve the problem, FSC required both registered and unregistered executives whose total remuneration is 500 million Won or more to disclosure their compensation in 2016. Furthermore, in 2018, FSC extended the disclosure requirement to executives who earn more than 200 million Won or more in variable compensation provided as annual bonus and incentive pay.

According to regulations, publicly traded firms in Korea need to file information on executive compensation with two documents: an annual business report and annual report on corporate governance and remuneration system. The annual business report, which is the Korean version of Form 10K, provides the information on executive pay (total remuneration of 500 million Won or more) as well as the process of determining executive remuneration. The annual report on the corporate governance and remuneration system discloses information on the responsibility and structure of the compensation committee, and components of all executive compensation, such as salary, bonus, stock option value, pension benefit, and other payments. As of now, Korean non-life insurance companies file their annual business report and annual report on corporate governance and remuneration system with FSC's electric disclosure system (DART) and on the website of Korean Non-life Insurance Association (KNIA), respectively, within three months after the end of the fiscal year.

\section{Sample and Methodology}

Our sample covers publicly traded Korean non-life insurers and US property-liability insurers that have reported CEO compensation over the period 2013-2018. For each year, we check the compensation section of Korean non-life insurance firms' annual business report filed with DART (Korean version of EDGAR), which includes their CEO's total remuneration and components in terms of salary, annual bonus, stock-based payment, and other payments. ${ }^{3}$ We manually collected the CEO compensation data for each Korean insurance company. Data on CEO age and tenure was obtained from firms' annual reports on corporate governance and remuneration systems. We extracted data on firm characteristics from the financial statement filed with the Korea Insurance Development Institute (KIDI), and data on stock return and market value were obtained from the Yonhap Infomax database. Our final sample consists of 33 firm-year observations from 8 public Korean non-life insurance companies from 2013-2018. ${ }^{4}$ For US publicly traded property-liability insurance firms, the data source for CEO compensation and CEO characteristics are collected from the ExecuComp database. Data on stock return and market capitalization are extracted from the Center for Research in Security Prices (CRSP). Data on public propertyliability insurers come from the National Association of Insurance Commissioners (NAIC) annual statements. Our sample includes 167 firm-year observations from 32 US public property-liability insurers over the period 2013-2018. 


\section{Methodologies}

To examine the determinants of CEO compensation in Korean non-life insurance firms, we performed regression analyses by including firm characteristics as well as information on CEO attributes. The estimates of coefficients derived from ordinary least squares (OLS) regression may be biased if there are some unknown variables or variables that cannot be controlled for that affect the dependent variable (Greene 2011). To address this potential bias, we employed a two-way fixed effects model. ${ }^{5}$ Since we examine publicly traded Korean non-life insurers ( 8 firms in total), our sample size is small, with an unbalanced panel of 33 observations. To deal with a small sample size, we employ a bootstrap approach for the statistical test of significance. To do so, we first draw 1000 bootstrap samples from our original sample with replacements. Next, we run the regressions with White-corrected standard errors to compute the heteroskedasticity-consistent $t$-statistic of the coefficients for the bootstrap samples. The adjusted bootstrap $t$-statistics generate an empirical distribution to compare against the $t$-statistic obtained from the original data. This bootstrap process creates $p$-values robust to heteroskedasticity. Given the cross-sectional and time-series data structure, the basic regression specification of our two-way fixed effects model can be expressed as follows:

$\operatorname{Ln}\left(\operatorname{Comp}_{\mathrm{i}, \mathrm{t}}\right)=\beta_{0}+\beta_{1} \ln (\text { Firm Size })_{\mathrm{i}, \mathrm{t}}+\beta_{2} \mathrm{ROA}_{\mathrm{i}, \mathrm{t}}+\beta_{3}$ Leverage $_{\mathrm{i}, \mathrm{t}}+\beta_{4}$ ProdHHI $_{\mathrm{i}, \mathrm{t}}+$ $\beta_{5}$ Volatility $_{i, t}+\beta_{6}$ Lossratio $_{i, t}+\beta_{7}$ CEO Age $_{i, t}+\beta_{8}$ CEO Tenure $i, t+d_{t}+f_{i}+\varepsilon_{i, t}$

where $i$ indexes the insurance firm and $t$ represents time (year), Comp $p_{i, t}$ is one of several types of CEO compensation measures, such as salary, annual bonus, total compensation for firm $i$ at time $t$. $d_{t}$ is a vector of time fixed-effects, $f_{i}$ is a vector of firm fixed-effects, and $\varepsilon_{i, t}$ is the error term. The definition of explanatory variables is described in the next Section.

With respect to the relationship between performance-based compensation and firm performance, we employed the following regression model:

Performance $_{i, t}$

$$
\begin{aligned}
& =\beta_{0}+\beta_{1} \% \text { Variable Pay }+\beta_{2} \ln \left(\text { Firm Size }_{i, t}+\beta_{3} \text { Leverage }_{i, t}\right. \\
& +\beta_{4} \text { ProdHHI }_{i, t}+\beta_{5} \text { Volatility }_{1}+\beta_{6} \text { Lossratio }_{i, t_{i, t}}+\beta_{7} \text { CEO Age }_{i, t} \\
& +\beta_{8} \text { CEO Tenure }_{i, t}+d_{t}+f_{i}+\varepsilon_{i, t}
\end{aligned}
$$

where Performance $i_{i, t}$ is one of several types of performance measures, such as ROA, ROE, and Tobin's $Q$ for firm i at time $t$.

For the analysis of CEO pay-performance sensitivity in Korean non-life insurance firms, we followed Jensen and Murphy (1990) by using the following regression model:

$$
\Delta\left(\text { Comp }_{i, t}\right)=\beta_{0}+\beta_{1} \Delta(S W)_{i, t}+\beta^{\prime} \times X_{i, t}+d_{t}+f_{i}+\varepsilon_{i, t}
$$

where the dependent variable is a change in CEO pay in a year. The main explanatory variable is the change in firm's shareholder wealth (SW) in that year, as measured by the stock return rate multiplied by the beginning-of-year firm market value. $X_{i, t}$ is a vector of control variables.

\section{Variables}

To measure CEO compensation, we employed several managerial compensation variables, including salary, bonus, and total compensation ${ }^{6}$. We utilized the natural logarithm of CEO salary, annual bonus or CEO total remuneration to mitigate skewness. Prior studies argue that a variety of factors could affect managerial compensation. First, the effect of executive compensation on firm performance has been widely studied. The literature has found that managerial compensation is positively associated with firm performance (Murphy 1985; Hall and Liebman 1998; Bertrand 2009; Kuo et al. 2013). Therefore, we expect a positive relationship between return on assets (ROA) and CEO compensation measures. ROA is calculated as the ratio of net income to total admitted assets. Second, some 
studies show that firm size is an important determinant of executive compensation. Core et al. (1999) find that larger firms with more growth opportunities and complex operations tend to offer managers higher compensation. Frydman and Saks (2010) point out that firms' competition for scarce managerial talent results in higher CEO compensation in larger companies. Thus, we predict that firm size is positively related to CEO pay. We compute an insurer size as a natural log of total admitted assets. Third, previous studies report that as a firm increases its leverage ratio (i.e., ratio of total debt to total assets), the firm's bankruptcy risk increases and consequently, high probability of bankruptcy leads to poor firm performance and lower managerial compensation (e.g., Houston and James 1995; Kato et al. 2005). Firth et al. (2006) contend that firms with high leverage are subject to intense monitoring by debtholders, and thus, CEOs of those firms cannot control the pay-setting process due to restrictions on their managerial discretion. Based on these findings, we anticipate that there is a negative relationship between leverage and CEO compensation. We measure leverage by the ratio of net premium written to policyholders' surplus.

Fourth, the literature states that diversified firms that have complex operations tend to provide CEOs with a higher compensation in an effort to hire and retain highly skilled CEOs (e.g., Schmidt and Fowler 1990; Rose and Shepard 1997). Thus, we expect that product concentration is negatively associated with CEO compensation. Product concentration (ProdHHI) is computed by the sum of the squares of the value of net written premiums in line $i$ divided by total net written premiums. ${ }^{7}$ Fifth, prior studies report that CEO pay is higher at firms with greater business risk because CEOs tend to demand a higher level of risk premium to protect their personal portfolio (e.g., Lippert and Moore 1994; Lippert and Porter 1997). On the other hand, Lambert and Larcker (1987) and Garvey and Milbourn (2003) point out that as a volatility of stock return increases, firms are more likely to reduce equity-based compensation. Choi et al. (2015) find that ROA is negatively related to the volatility of firm performance. Taken together, it is expected that firms with higher level of volatility of firm performance tend to offer low CEO pay due to poor firm performance. Given these different views, the effect of volatility of firm performance on CEO compensation is unclear. Volatility of firm performance is measured as the standard deviation of return on assets (ROA) over the past five years.

Sixth, insurance firms with high loss ratio tend to achieve poor firm performance, since they have a high level of underwriting risk (e.g., Malik 2011; Kaya 2015). We thus expect that loss ratio is negatively related to CEO compensation. Loss ratio is the ratio of the claims paid by an insurer to the premiums earned. Seventh, as CEOs age, they become more experienced and have enhanced managerial skills. In this situation, it is difficult for firms to replace those CEOs, thus resulting in high CEO compensation (Finkelstein et al. 2000; Conyon and Murphy 2000; Alves et al. 2016). This leads to the hypothesis that CEO age is positively associated with $\mathrm{CEO}$ compensation. $\mathrm{CEO}$ age means the age of $\mathrm{CEO}$ in years. Lastly, the literature shows that as CEO tenure increases, the influence that CEOs have over the board of directors also increases, leading to higher levels of CEO compensation (e.g., Hill and Phan 1991; Cordeiro and Veliyath 2003; Ozkan 2011). Therefore, we predict a positive relation between $\mathrm{CEO}$ tenure and CEO pay. CEO tenure is the number of years that a $\mathrm{CEO}$ has been in the current position. The definitions of variables are summarized in Table 1. 
Table 1. Variables Definitions.

\begin{tabular}{ll}
\hline Salary & \multicolumn{1}{c}{ Variable } \\
Bonus & $\begin{array}{l}\text { The value of a fixed regular payment, made by CEO during the fiscal year } \\
\text { The value of a form of variable compensation, earned by CEO during the fiscal year, especially as a } \\
\text { reward if annual objected were achieved } \\
\text { Sum of salary, bonus, and other annual compensation for Korean non-life insurers; sum of salary, } \\
\text { annual bonus, value of options granted, restricted stock grants, long-term incentive plan (LTIP) } \\
\text { payouts, and all other compensation for US property-liability insurers }\end{array}$ \\
Total Compensation & Natural log of an insurer's total admitted assets \\
Firm Size & Ratio of net income to total admitted assets \\
ROA & Ratio of net income to equity capital \\
& Market value of assets divided by the book value of assets. Market value of assets is the total assets \\
poE & plus market value of equity minus book value of equity. Book value of equity is measured as \\
sobin's Q & Change in firm's shareholder wealth (SW) in that year. SW is measured as the stock return rate \\
& multiplied by the beginning-of-year firm market value \\
CSW & Ratio of net premium written (NPW) to policyholders' surplus \\
Leverage & Sum of the squares of the percentages of direct premium written across product lines \\
ProdHHI & 5-year standard deviation of return on assets (ROA) \\
Volatility & Ratio of the claims paid by an insurer to the premiums earned \\
Loss Ratio & Age of CEO in years \\
CEO Age & Number of years that CEO has been in the current position \\
CEO Tenure &
\end{tabular}

\section{Results}

\subsection{Summary Statistics}

Table 2 reports summary statistics for variables used in our analyses. The average of salary, annual bonus, other payment, and total compensation are 566 million Won, 440 million Won, 140 million Won, and 1.15 billion Won, respectively. The component of salary consists of approximately 50 percent of a CEO's total compensation. These findings indicate that a salary is dominant in the CEO compensation package in Korean non-life insurance firms. Surprisingly, stock-based compensation, such as stock options and restricted stocks, do not consist of CEO compensation for Korean non-life insurance companies. With regard to CEO characteristics, the means of CEO age and tenure are 59 years and 2.4 years, respectively. This implies that CEOs of Korean non-life insurance firms have a short tenure.

Table 2. Summary Statistics of Variables (Korean Non-life Insurance Firms).

\begin{tabular}{ccccccc}
\hline Variable & Obs. & Mean & Min. & Med. & Max. & Std Dev \\
\hline Salary & 33 & 566.000 & 308.000 & 519.000 & 758.000 & 135.000 \\
Bonus & 33 & 440.000 & 0.000 & 353.000 & 2578.000 & 485.000 \\
Other & 33 & 140.000 & 0.000 & 18.000 & 2803.000 & 540.000 \\
Total Compensation & 33 & 1146.000 & 520.000 & 886.000 & 3401.000 & 671.000 \\
Firm Size & 33 & 16.582 & 15.474 & 16.273 & 18.184 & 0.737 \\
ROA & 33 & 0.012 & -0.005 & 0.009 & 0.070 & 0.015 \\
ROE & 33 & 0.087 & -0.079 & 0.085 & 0.152 & 0.047 \\
Tobin's Q & 33 & 0.929 & 0.552 & 0.981 & 1.097 & 0.141 \\
Leverage & 33 & 0.879 & 0.460 & 0.921 & 0.955 & 0.117 \\
ProdHHI & 33 & 0.590 & 0.387 & 0.563 & 1.0000 & 0.180 \\
Volatility & 33 & 0.226 & 0.057 & 0.213 & 0.418 & 0.104 \\
Loss Ratio & 33 & 0.807 & 0.493 & 0.855 & 0.911 & 0.111 \\
CEO Age & 33 & 59.273 & 53.000 & 59.000 & 67.500 & 3.689 \\
CEO Tenure & 33 & 2.368 & 0.500 & 2.016 & 5.833 & 1.747 \\
\hline
\end{tabular}

Note: For CEO compensation variables, such as salary, bonus, other, total compensation, the measurement unit is Million Won. 


\subsection{Empirical Results}

\subsubsection{Determinants of CEO Pay}

The estimates of the parameters of determinants of CEO compensation in Korean non-insurance companies from our two-way fixed effects model are presented in Table 3. Note that we use bootstrap standard error robust to heteroskedasticity. The coefficient of ROA is statistically significant and positive at the 1 percent level for annual bonus and total CEO compensation. These results indicate that performance-based compensation, which is annual bonus, is closely linked to the insurer's financial performance. Underwriting leverage and volatility of ROA are significantly and negatively related to annual bonus, implying that higher leverage and volatility of firm performance are associated with higher insolvency risk (Carson and Hoyt 1995), thereby leading to a low level of CEO compensation. The coefficients of CEO age and tenure are statistically significant and positive at the 5 percent level for CEO salary. These results are consistent with Hill and Phan (1991) who demonstrated that as CEOs get older and have longer tenures, they are more likely to be highly compensated. This demonstrates an important role of seniority in CEO compensation practices in Korean non-life insurance companies.

Table 3. Determinants of CEO Compensation (Korean Non-life Insurance Firms) using the Bootstrap Approach.

\begin{tabular}{|c|c|c|c|}
\hline Dependent Variable & Log (Salary) & Log (Bonus) & Log (Total) \\
\hline \multirow{3}{*}{ Intercept } & (1) & (2) & (3) \\
\hline & 0.161 & 1.238 & 1.438 \\
\hline & $(0.546)$ & $(6.739)$ & (1.305) \\
\hline \multirow{2}{*}{ Firm Size } & 0.676 & 0.445 & 0.770 \\
\hline & $(0.421)$ & $(0.320)$ & $(0.545)$ \\
\hline \multirow[t]{2}{*}{ ROA } & 1.621 & $0.874^{* * *}$ & $1.430^{* * *}$ \\
\hline & $(2.186)$ & $(0.269)$ & $(0.435)$ \\
\hline \multirow[t]{2}{*}{ Leverage } & -1.023 & $-7.500 * *$ & $-1.196^{* *}$ \\
\hline & $(2.985)$ & $(3.683)$ & $(0.526)$ \\
\hline \multirow[t]{2}{*}{ ProdHHI } & 0.724 & 0.652 & 0.562 \\
\hline & $(0.939)$ & $(1.158)$ & $(1.478)$ \\
\hline \multirow[t]{2}{*}{ Volatility } & -1.068 & $-4.425^{* * *}$ & -2.989 \\
\hline & $(0.805)$ & $(0.993)$ & $(1.899)$ \\
\hline \multirow[t]{2}{*}{ Loss Ratio } & -0.857 & -0.235 & -1.383 \\
\hline & $(1.532)$ & $(0.169)$ & $(2.218)$ \\
\hline \multirow{2}{*}{ CEO Age } & $0.104^{* * *}$ & 0.470 & 0.154 \\
\hline & $(0.020)$ & $(0.311)$ & $(0.417)$ \\
\hline \multirow{2}{*}{ CEO Tenure } & $0.020^{* * *}$ & 0.109 & 0.097 \\
\hline & $(0.004)$ & $(0.075)$ & $(0.089)$ \\
\hline Year fixed effects & Yes & Yes & Yes \\
\hline Firm fixed effects & Yes & Yes & Yes \\
\hline Observations & 33 & 33 & 33 \\
\hline Adjusted R-squared & 0.428 & 0.560 & 0.472 \\
\hline
\end{tabular}

5 percent, and 1 percent level, respectively. See Table 1 for variable definitions.

\subsubsection{Pay-Performance Sensitivity}

Table 4 presents the results of CEO pay-performance sensitivity in Korean non-life insurance firms where the dependent variable is the change in salary, bonus, or total CEO compensation, respectively, and the primary variable of interest is the change in the firm's shareholder wealth (SW). The coefficient of $\Delta S W$ indicates the pay-performance sensitivity. We performed the test for different forms of CEO pay, separately, in order to identify their different effects on the pay-performance relationship. The results in Table 4 show a remarkable difference in the pay-performance relationship among different types of CEO compensation. The coefficient of pay-performance sensitivity is only positively and statistically significant at the 1 percent level for annual bonus, whereas it is not 
statistically significant for both salary and total CEO compensation. These results indicate the different impacts of fixed base salary and performance-based pay on shareholder value. For annual bonus, the coefficient on $\Delta \mathrm{SW}$ yields an average sensitivity of 0.031 for CEO pay to shareholder wealth. This indicates that the change in shareholder wealth is positively associated with annual bonus, implying that insurers that have an increase in shareholder wealth tend to display an increase in annual bonus. Overall, these results suggest that performance-based pay, such as bonus, in the design of CEO compensation would be more effective than fixed base salary in enhancing shareholder value. This finding is consistent with Hall and Liebman (1998) who found that as CEO compensation changes in favor of incentive-based pay structure, the sensitivity of pay to performance increases.

Table 4. CEO Compensation-Performance Sensitivity (Korean Non-life Insurance Firms) using the Bootstrap Approach.

\begin{tabular}{|c|c|c|c|}
\hline Dependent Variable & $\Delta$ Salary & $\Delta$ Bonus & $\Delta$ Total \\
\hline \multirow[t]{2}{*}{ Intercept } & 2.284 & 3.287 & 3.605 \\
\hline & (5.587) & (2.499) & $(5.514)$ \\
\hline \multirow[t]{2}{*}{$\Delta \mathrm{SW}$} & 0.003 & $0.031^{* * *}$ & 0.007 \\
\hline & $(0.002)$ & $(0.003)$ & $(0.015)$ \\
\hline \multirow{2}{*}{ Firm Size } & 0.564 & 0.143 & 0.636 \\
\hline & $(0.376)$ & $(0.098)$ & $(0.531)$ \\
\hline \multirow[t]{2}{*}{ ROA } & 1.696 & $1.076^{* * *}$ & $0.805^{* * *}$ \\
\hline & $(2.224)$ & $(0.244)$ & $(0.221)$ \\
\hline \multirow{2}{*}{ Leverage } & -1.642 & $-7.982^{* * *}$ & $-6.117^{* *}$ \\
\hline & $(3.061)$ & $(1.679)$ & $(3.027)$ \\
\hline \multirow[t]{2}{*}{ ProdHHI } & 0.798 & $0.637^{* * *}$ & 0.784 \\
\hline & $(0.955)$ & $(0.090)$ & $(1.058)$ \\
\hline \multirow[t]{2}{*}{ Volatility } & -1.001 & -4.085 & -2.108 \\
\hline & $(0.823)$ & $(4.199)$ & $(1.634)$ \\
\hline \multirow[t]{2}{*}{ Loss Ratio } & -0.613 & -0.419 & -1.782 \\
\hline & $(1.570)$ & $(0.861)$ & $(1.312)$ \\
\hline \multirow{2}{*}{ CEO Age } & $0.103^{* * *}$ & 0.660 & 0.085 \\
\hline & $(0.021)$ & $(0.764)$ & $(0.416)$ \\
\hline \multirow{2}{*}{ CEO Tenure } & $0.022^{* * *}$ & 0.147 & 0.069 \\
\hline & $(0.004)$ & $(0.122)$ & $(0.089)$ \\
\hline Year fixed effects & Yes & Yes & Yes \\
\hline Firm fixed effects & Yes & Yes & Yes \\
\hline Observations & 33 & 33 & 33 \\
\hline Adjusted R-squared & 0.409 & 0.640 & 0.219 \\
\hline
\end{tabular}

Note: Bootstrap standard error robust to heteroskedasticity are in parentheses. ${ }^{*}, * *, * * *$ significant at 10 percent, 5 percent, and 1 percent level, respectively. See Table 1 for variable definitions.

To further investigate whether performance-based pay increases firm performance, we next examine the effect of variable pay (i.e., bonus), which is the portion of CEO compensation determined by performance, on a firm's financial profitability and value. In this analysis, our main explanatory variable is the percentage of bonus in CEO total compensation (\%Variable Pay). Table 5 reports the estimations of the parameters of the relationship between variable pay and firm performance. The coefficients of \%Variable Pay are statistically significant and positive in ROA, ROE, and Tobin's $Q$, implying that Korean non-life insurers who provide CEOs with more performance-based pay tend to achieve better financial profitability and firm value. These results imply that Korean non-life insurance firms could motivate CEOs to exert their best efforts to enhance firm performance by increasing the proportion of variable pay closely linked to performance in the design of CEO compensation.

With respect to control variables, the coefficients of underwriting leverage and volatility of ROA are significant and negative in Tobin's $Q$ and ROE, respectively. This indicates that firms with high level of leverage and volatility of firm performance engage more in 
financial distress, thereby resulting in low firm performance (Opler and Titman 1993). Loss ratio is significantly and negatively related to insurer's firm performance, implying that insurers with high loss ratio may be in poor financial health, and therefore, achieve low firm performance. The coefficient of CEO tenure is significant and positive in all three measures of firm performance. This result is consistent with Khan and Vieito (2013) that long-tenured CEOs are more likely to have better firm performance because of their deeper understanding of business processes and work culture of the company. Considering the short tenure of Korean non-life insurance firms (currently less than 3 years), this result suggests that Korean non-life insurers need to increase tenure of CEOs in order to improve firm's financial profitability and long-term firm value.

Table 5. Effect of Variable Pay on Firm Performance (Korean Non-life Insurance Firms) using the Bootstrap Approach.

\begin{tabular}{cccc}
\hline Dependent Variable & ROA & ROE & Tobin's Q \\
\hline Intercept & 0.208 & 0.228 & 1.379 \\
& $(0.181)$ & $(1.169)$ & $(0.803)$ \\
\%Variable Pay & $0.096^{* * *}$ & $0.103 * *$ & $0.132^{* *}$ \\
& $(0.028)$ & $(0.050)$ & $(0.050)$ \\
Firm Size & 0.010 & 0.040 & 0.023 \\
& $(0.024)$ & $(0.056)$ & $(0.039)$ \\
Leverage & -0.085 & -0.427 & $-0.974^{* *}$ \\
ProdHHI & $(0.178)$ & $(0.644)$ & $(0.391)$ \\
& 0.112 & 0.032 & 0.035 \\
Volatility & $(0.075)$ & $(0.199)$ & $(0.140)$ \\
& -1.635 & $-3.384 * *$ & $(11.722)$ \\
Loss Ratio & $(1.470)$ & $(1.179)$ & $-1.464^{* * *}$ \\
& $-0.185^{* * *}$ & $-0.543^{* * *}$ & $(0.349)$ \\
CEO Age & $(0.030)$ & $(0.162)$ & 0.007 \\
& 0.003 & 0.002 & $(0.005)$ \\
CEO Tenure & $(0.002)$ & $(0.009)$ & $0.009^{* * *}$ \\
& $0.012^{* * *}$ & $0.019 * * *$ & $(0.002)$ \\
\hline Year fixed effects & $(0.002)$ & $(0.005)$ & Yes \\
Firm fixed effects & Yes & Yes & Yes \\
Observations & Yes & Yes & 33 \\
Adjusted R-squared & 33 & 33 & 0.858 \\
\hline
\end{tabular}

Note: Bootstrap standard error robust to heteroskedasticity are in parentheses. ${ }^{*},{ }^{* * *},{ }^{* * *}$ significant at 10 percent, 5 percent, and 1 percent level, respectively. See Table 1 for variable definitions.

5.2.3. Comparison of CEO Pay between Korean Non-Life Insurers and US Property-Liability Insurers

Next, we are interested in how CEO pay of Korean non-life insurers differs from that of US property-liability insurers. To do so, we perform the comparison of CEO compensation between Korean non-life insurers and their US counterparts. We convert all CEO compensation variables of Korean non-life insurers to 2018 U.S. dollars. We utilize an exchange rate adjusted by purchasing power parities (PPPs) from OECD statistics to take into account relative values of CEO compensation between Korean non-life insurers and US property-liability insurers. Table 6 reports summary statistics of CEO pay for the Korean and US insurer samples. The results show stark differences in both the level and structure of CEO compensation between insurance companies of two countries. Regarding the pay level (how much managers are paid), on average, CEOs of Korean non-life insurers earn $\$ 1.32$ million a year, which is only 20 percent of the U.S. counterparts of $\$ 6.46$ million. The differences in mean and median values of CEO pay variables (salary, annual bonus, and total CEO compensation) between two countries are statistically significant. This difference is remarkably large and contrasts with the findings of previous studies (Conyon et al. 2011; Fernandes et al. 2013). 
Table 6. Korea-US Comparison: Level and Structure of CEO Compensation.

\begin{tabular}{|c|c|c|c|c|c|c|c|c|c|c|c|}
\hline \multicolumn{6}{|c|}{ Korea } & \multicolumn{4}{|c|}{ US } & \multicolumn{2}{|c|}{ Korea-US Difference } \\
\hline \multicolumn{2}{|l|}{ Variables Unit } & \multirow{2}{*}{$\begin{array}{c}\text { Mean } \\
0.747\end{array}$} & \multirow{2}{*}{$\begin{array}{c}\text { Median } \\
0.543\end{array}$} & \multirow{2}{*}{$\begin{array}{c}\text { Std Dev } \\
0.113\end{array}$} & \multirow{2}{*}{$\begin{array}{l}\mathbf{N} \\
33\end{array}$} & \multirow{2}{*}{$\begin{array}{c}\text { Mean } \\
0.886\end{array}$} & \multirow{2}{*}{$\begin{array}{c}\text { Median } \\
0.869\end{array}$} & \multirow{2}{*}{$\begin{array}{c}\text { Std Dev } \\
0.131\end{array}$} & \multirow{2}{*}{$\frac{\mathbf{N}}{167}$} & \multirow{2}{*}{$\begin{array}{c}\text { Mean } \\
-0.139^{* * *}\end{array}$} & \multirow{2}{*}{$\begin{array}{c}\text { Median } \\
-0.326^{* * *}\end{array}$} \\
\hline Salary & Million USD & & & & & & & & & & \\
\hline Bonus & Million USD & 0.489 & 0.342 & 0.401 & 33 & 0.423 & 0.443 & 0.298 & 167 & 0.066 & $-0.101^{* *}$ \\
\hline Other Payments & Million USD & 0.088 & 0.065 & 0.035 & 33 & 0.251 & 0.244 & 0.230 & 167 & $-0.163^{* * *}$ & $-0.179 * * *$ \\
\hline Stock Options & Million USD & 0.000 & 0.000 & 0.000 & 33 & 0.637 & 0.570 & 0.228 & 167 & $-0.637^{* * *}$ & $-0.570 * * *$ \\
\hline Restricted Stock & Million USD & 0.000 & 0.000 & 0.000 & 33 & 2.508 & 2.415 & 1.904 & 167 & $-2.508^{* * *}$ & $-2.415^{* * *}$ \\
\hline Total Compensation & Million USD & 1.324 & 0.907 & 0.557 & 33 & 6.458 & 6.072 & 2.973 & 167 & $-5.134^{* * *}$ & $-5.165^{* * *}$ \\
\hline Salary/Total Compensation & Percentage & 0.564 & 0.544 & 0.209 & 33 & 0.137 & 0.143 & 0.163 & 167 & $0.427^{* * *}$ & $0.401^{* * *}$ \\
\hline Bonus/Total Compensation & Percentage & 0.369 & 0.437 & 0.214 & 33 & 0.065 & 0.073 & 0.083 & 167 & $0.304^{* * *}$ & $0.364^{* * *}$ \\
\hline $\begin{array}{l}\text { Stock Options/Total } \\
\text { Compensation }\end{array}$ & Percentage & 0.000 & 0.000 & 0.000 & 33 & 0.100 & 0.094 & 0.135 & 167 & $-0.100^{* * *}$ & $-0.094^{* * *}$ \\
\hline $\begin{array}{l}\text { Restricted Stock/Total } \\
\text { Compensation }\end{array}$ & Percentage & 0.000 & 0.000 & 0.000 & 33 & 0.388 & 0.397 & 0.453 & 167 & $-0.388^{* * *}$ & $-0.397^{* * *}$ \\
\hline
\end{tabular}

Exchange rate adjusted by Purchasing power parities (PPPs) from OECD statistics is used. ******* significant at 10 percent, 5 percent, and 1 percent level, respectively. 
Furthermore, we find another remarkable difference in pay structure between insurers of two countries. Specifically, CEOs of Korean non-life insurers are paid a dominant base salary with an average of $\$ 0.75$ million, which accounts for 56.4 percent of their total remuneration, whereas the average salary paid to CEOs of US property-liability insurers is about $\$ 0.89$ million, accounting for only 13.7 percent of their total compensation. However, total incentive pay, consisting of annual bonuses, stock options, and restricted stock awards, is $\$ 0.49$ million for Korean CEOs and \$3.56 million for US CEOs, which accounts for 36.9 percent and 55 percent of the total CEO compensation for Korean nonlife insurers and U.S. Property-liability insurers, respectively. This indicates that the low proportion of performance-based pay in Korean non-life insurers is in direct contrast to the high proportions of stock options and restricted stock in US counterparts. This suggests that Korean non-life insurer's CEOs tend to get a high portion of fixed pay regardless of their performance, and thus, less performance-based pay is provided for enhancing firm value relative to US counterparts. In particular, the fact that there is no stock-based compensation in CEO pay of Korean non-life insurance firms is contrary to the findings of prior literature (e.g., Conyon et al. 2013) that CEO compensation practices have converged into a US style pay system, which consists of a low portion of base salary and a large proportion of equity-based pay in CEO compensation, in place since the 2000s as a result of increased globalization of the world's economies.

Taken together, the above results imply that there may be significant differences in the determinants of CEO pay and the pay-performance relationship between insurance firms of two countries. To further explore this possibility, we follow Pan and Zhou (2018) and include the Korea dummy (the value of one for Korean non-life insurance firm, and zero for US property-liability insurance firms in baseline regression model (1)). Its interaction with each of the independent variables captures Korea-U.S. differences. Table 7 reports our results for the comparison of determinants of CEO pay. Note that the coefficients on the variables without the Korea dummy apply to CEOs of U.S. property-liability insurers and those with the dummy variable indicate the Korea-U.S. differences. We find that unlike Korean non-life insurers, firm size is significantly and positively related to CEO pay, such as salary and bonus for U.S. property-liability insurers. In addition to the differing size effect, US CEOs receive higher compensation in firms with higher product concentration. This result suggests that US property-liability insurer's CEOs are more likely to obtain a higher level of pay when the degree of product concentration increases because focused insurers tend to have greater financial performance (Shim 2011), and therefore, CEOs of these firms tend to get higher CEO pay. Volatility of ROA is negatively related to total compensation, indicating that volatility of firm performance is associated with low levels of firm performance for US property-liability insurers.

With respect to interaction terms, among all variables, we found that firm size, product concentration, and volatility of firm performance are the key factors affecting the difference in CEO compensation between US property-liability insurers and Korean non-life insurers. Specifically, the coefficient of interaction of Korea $\times$ Firm Size is significantly positive in bonus. This indicates that as an insurer size gets larger, CEOs of Korean non-life insurance firms tend to receive higher bonuses compared to US counterparts. Korea $\times$ ProdHHI is significantly and negatively related to bonus, suggesting that CEOs of Korean non-life insurers are likely to get paid with higher bonuses in insurers with lower (higher) line-of-business concentration (diversification) relative to US property-liability insurers. Interaction term of Korea $\times$ Volatility is positively and significantly associated with base salary and total compensation. This implies greater compensation to CEOs of Korean non-life insurance firms for taking more risk. Overall, these results suggest that difference in CEO pay in Korea-U.S. insurance firms may result from a function of some firm characteristics. 
Table 7. Comparison of Determinants of CEO Compensation using the Bootstrap Approach.

\begin{tabular}{|c|c|c|c|}
\hline Dependent Variable & Log (Salary) & Log (Bonus) & Log (Total) \\
\hline Intercept & $\begin{array}{c}5.205^{* * *} \\
(0.418)\end{array}$ & $\begin{array}{l}9.271^{* * *} \\
(2.514)\end{array}$ & $\begin{array}{c}12.168 \\
(16.713)\end{array}$ \\
\hline Firm Size & $\begin{array}{l}0.034^{* *} \\
(0.019)\end{array}$ & $\begin{array}{c}0.432 * * * \\
(0.146)\end{array}$ & $\begin{array}{c}0.502 \\
(0.749)\end{array}$ \\
\hline ROA & $\begin{array}{c}0.108 \\
(1.023)\end{array}$ & $\begin{array}{c}0.398 \\
(0.457)\end{array}$ & $\begin{array}{l}0.571^{*} \\
(0.341)\end{array}$ \\
\hline leverage & $\begin{array}{l}-0.076 \\
(0.059)\end{array}$ & $\begin{array}{l}-0.113 \\
(0.157)\end{array}$ & $\begin{array}{l}-0.225 \\
(0.291)\end{array}$ \\
\hline ProdHHI & $\begin{array}{c}0.317^{* * *} \\
(0.090)\end{array}$ & $\begin{array}{c}1.890^{* * *} \\
(0.637)\end{array}$ & $\begin{array}{c}0.701 \\
(0.776)\end{array}$ \\
\hline Volatility & $\begin{array}{l}-3.074^{* *} \\
(1.475)\end{array}$ & $\begin{array}{l}-0.265 \\
(1.021)\end{array}$ & $\begin{array}{l}-1.416^{* * *} \\
(0.237)\end{array}$ \\
\hline Loss Ratio & $\begin{array}{c}-0.023 \\
(0.018)\end{array}$ & $\begin{array}{l}-0.004 \\
(0.026)\end{array}$ & $\begin{array}{c}-0.068 \\
(0.061)\end{array}$ \\
\hline CEO Age & $\begin{array}{c}0.005 \\
(0.005)\end{array}$ & $\begin{array}{c}0.013 \\
(0.026)\end{array}$ & $\begin{array}{c}0.024 \\
(0.067)\end{array}$ \\
\hline CEO Tenure & $\begin{array}{c}0.012 \\
(0.033)\end{array}$ & $\begin{array}{c}0.034 \\
(0.031)\end{array}$ & $\begin{array}{l}0.180^{* * *} \\
(0.055)\end{array}$ \\
\hline Korea & $\begin{array}{c}0.159 \\
(0.488)\end{array}$ & $\begin{array}{c}0.150 \\
(0.163)\end{array}$ & $\begin{array}{c}0.162 \\
(0.0 .194)\end{array}$ \\
\hline Korea $\times$ Firm Size & $\begin{array}{c}0.042 \\
(0.228)\end{array}$ & $\begin{array}{l}1.551^{* * *} \\
(0.271)\end{array}$ & $\begin{array}{c}0.433 \\
(0.611)\end{array}$ \\
\hline Korea $\times$ ROA & $\begin{array}{l}-2.798 \\
(2.103)\end{array}$ & $\begin{array}{l}-0.841 \\
(0.736)\end{array}$ & $\begin{array}{l}-0.694 \\
(0.885)\end{array}$ \\
\hline Korea $\times$ Leverage & $\begin{array}{l}-1.038 \\
(2.760)\end{array}$ & $\begin{array}{c}0.531 \\
(0.572)\end{array}$ & $\begin{array}{c}0.634 \\
(1.021)\end{array}$ \\
\hline Korea $\times$ ProdHHI & $\begin{array}{l}-0.238 \\
(0.827)\end{array}$ & $\begin{array}{c}-1.534^{* * *} \\
(0.501)\end{array}$ & $\begin{array}{l}-1.263 \\
(1.313)\end{array}$ \\
\hline Korea $\times$ Volatility & $\begin{array}{l}2.976^{*} \\
(1.637)\end{array}$ & $\begin{array}{c}2.939 \\
(2.111)\end{array}$ & $\begin{array}{l}1.035^{* * *} \\
(0.260)\end{array}$ \\
\hline Korea $\times$ Loss Ratio & $\begin{array}{c}0.182 \\
(1.355)\end{array}$ & $\begin{array}{c}0.471 \\
(0.505)\end{array}$ & $\begin{array}{c}0.202 \\
(0.215)\end{array}$ \\
\hline Korea $\times$ CEO Age & $\begin{array}{l}-0.006 \\
(0.005)\end{array}$ & $\begin{array}{l}-0.025 \\
(0.072)\end{array}$ & $\begin{array}{l}-0.038 \\
(0.029)\end{array}$ \\
\hline Korea $\times$ CEO Tenure & $\begin{array}{c}0.006 \\
(0.007)\end{array}$ & $\begin{array}{c}0.015 \\
(0.013)\end{array}$ & $\begin{array}{c}0.009 \\
(0.008)\end{array}$ \\
\hline Year fixed effects & Yes & Yes & Yes \\
\hline Firm fixed effects & Yes & Yes & Yes \\
\hline Observations & 200 & 200 & 200 \\
\hline Adjusted R-squared & 0.409 & 0.596 & 0.283 \\
\hline
\end{tabular}

Note: Bootstrap standard error robust to heteroskedasticity are in parentheses. ${ }^{*},{ }^{* *},{ }^{* * *}$ significant at 10 percent, 5 percent, and 1 percent level, respectively. See Table 1 for variable definitions.

Finally, we compare the pay-performance sensitivity between two countries' insurance firms. To do so, we perform regressions by adding a dummy variable for Korean non-life insurance firms and their interaction with $\Delta S W$ in baseline model (2). The interaction term captures the average difference in the pay-performance sensitivity between Korean non-life insurers and US counterparts. ${ }^{8}$ Table 8 reports the regression results. The coefficient of $\Delta \mathrm{SW}$ is significantly positive at the 1 percent level for annual bonus. This implies that there is a strong pay-performance relationship in US property-liability insurance firms. Moreover, we find that fixed base salary in CEO compensation does not change with the firm's shareholder value in US property-liability insurers, which is the same as the result of Korean non-life insurers. Among the different types of CEO pay, the coefficient of Korea $\times \Delta \mathrm{SW}$ is statistically significant and negative in bonus at the 5 percent level. This means that performance-based pay, such as bonus, is less sensitive to shareholder value in Korean non-life insurers compared to US counterparts. These results are consistent with 
the findings in Japanese firms of Pan and Zhou (2018). Therefore, our results suggest that Korean non-life insurers need to build a stronger pay-for-performance relationship by more concretely linking performance-based compensation to shareholder value in the design of CEO pay.

Table 8. Comparison of Compensation-performance Sensitivity using the Bootstrap Approach.

\begin{tabular}{|c|c|c|c|}
\hline Dependent Variable & $\Delta$ Salary & $\Delta$ Bonus & $\Delta$ Total \\
\hline Intercept & $\begin{array}{c}5.107^{* * *} \\
(0.402)\end{array}$ & $\begin{array}{c}10.803^{* * *} \\
(2.017)\end{array}$ & $\begin{array}{c}8.873^{* * *} \\
(1.164)\end{array}$ \\
\hline Korea & $\begin{array}{c}-0.741^{* * *} \\
(0.130)\end{array}$ & $\begin{array}{l}-1.068 \\
(1.100)\end{array}$ & $\begin{array}{c}-2.018^{* * *} \\
(0.376)\end{array}$ \\
\hline$\Delta \mathrm{SW}$ & $\begin{array}{c}0.002 \\
(0.005)\end{array}$ & $\begin{array}{c}0.061^{* * *} \\
(0.020)\end{array}$ & $\begin{array}{c}0.006 \\
(0.012)\end{array}$ \\
\hline Korea $\times \Delta \mathrm{SW}$ & $\begin{array}{l}-0.001 \\
(0.002)\end{array}$ & $\begin{array}{c}-0.017^{* * *} \\
(0.005)\end{array}$ & $\begin{array}{l}-0.002 \\
(0.006)\end{array}$ \\
\hline Firm Size & $\begin{array}{c}0.036^{* *} \\
(0.018)\end{array}$ & $\begin{array}{c}0.408^{* * *} \\
(0.037)\end{array}$ & $\begin{array}{c}0.105^{* *} \\
(0.052)\end{array}$ \\
\hline ROA & $\begin{array}{c}0.525 \\
(0.641)\end{array}$ & $\begin{array}{l}1.120 \\
(1.205)\end{array}$ & $\begin{array}{c}1.205 \\
(1.854)\end{array}$ \\
\hline leverage & $\begin{array}{l}-0.046 \\
(0.049)\end{array}$ & $\begin{array}{l}-0.159 \\
(0.901)\end{array}$ & $\begin{array}{c}-0.319 * * \\
(0.151)\end{array}$ \\
\hline ProdHHI & $\begin{array}{c}0.147 \\
(0.179)\end{array}$ & $\begin{array}{c}0.059 \\
(1.115)\end{array}$ & $\begin{array}{c}0.338 \\
(0.257)\end{array}$ \\
\hline Volatility & $\begin{array}{l}-0.129 \\
(0.487)\end{array}$ & $\begin{array}{l}-0.200 \\
(2.960)\end{array}$ & $\begin{array}{l}-1.684 \\
(1.406)\end{array}$ \\
\hline Loss Ratio & $\begin{array}{c}-0.003^{* * *} \\
(0.001)\end{array}$ & $\begin{array}{l}-0.026 \\
(0.025)\end{array}$ & $\begin{array}{l}-0.025 \\
(0.059)\end{array}$ \\
\hline CEO Age & $\begin{array}{l}0.006^{* *} \\
(0.003)\end{array}$ & $\begin{array}{c}0.013 \\
(0.021)\end{array}$ & $\begin{array}{c}0.007 \\
(0.011)\end{array}$ \\
\hline CEO Tenure & $\begin{array}{c}0.010 \\
(0.024)\end{array}$ & $\begin{array}{c}0.002 \\
(0.005)\end{array}$ & $\begin{array}{c}0.001 \\
(0.003)\end{array}$ \\
\hline Year fixed effects & Yes & Yes & Yes \\
\hline Firm fixed effects & Yes & Yes & Yes \\
\hline Observations & 200 & 200 & 200 \\
\hline Adjusted R-squared & 0.431 & 0.754 & 0.566 \\
\hline
\end{tabular}

5 percent, and 1 percent level, respectively. See Table 1 for variable definitions.

\subsection{Robustness Check}

To address the potential endogeneity issues, we employ a dynamic panel estimator, such as system GMM estimator (Blundell and Bond 1998). System GMM is commonly used to control for endogeneity that could arise in dynamic models by using the internally generated instruments. For more on the method, see Wooldridge (2002). To do this, we include one lag of CEO compensation measures in the model and proceed with a dynamic panel model. Tables 9 and 10 report the results estimated using the system-GMM estimator. First, Tables 9 and 10 provide the results of the two specification tests, which are the Hansen test of overidentifying restrictions and the autocorrelation test. The results indicate that over-identifying restrictions specified in the model are valid and there is no evidence of second-order autocorrelation in the residuals. In Tables 9 and 10, $\Delta$ (Comp)t-1, the coefficient for the lagged dependent variable is significant and positive. This implies that the remuneration committees may use past $\mathrm{CEO}$ compensation as a reference when they set up current compensation (Bender 2003). More importantly, Tables 9 and 10 show that our main findings remain the same as those in Tables 7 and 8 . These results suggest that our main empirical results are robust to the endogeneity problem. 
Table 9. Comparison of Determinants of CEO Compensation using system GMM.

\begin{tabular}{|c|c|c|c|}
\hline Dependent Variable & Log (Salary) & Log (Bonus) & Log (Total) \\
\hline Intercept & $\begin{array}{c}2.437^{* * *} \\
(0.398)\end{array}$ & $\begin{array}{c}12.706^{* *} \\
(7.185)\end{array}$ & $\begin{array}{c}5.718^{* * *} \\
(0.645)\end{array}$ \\
\hline $\log ($ Salary $) \mathrm{t}-1$ & $\begin{array}{c}0.602^{* * *} \\
(0.050)\end{array}$ & & \\
\hline $\log$ (Bonus)t-1 & & $\begin{array}{c}0.024^{* *} \\
(0.012)\end{array}$ & \\
\hline Log(Total)t-1 & & & $\begin{array}{c}0.039^{* * *} \\
(0.011)\end{array}$ \\
\hline Firm Size & $\begin{array}{c}0.032 * * \\
(0.013)\end{array}$ & $\begin{array}{c}0.672^{* * *} \\
(0.211)\end{array}$ & $\begin{array}{c}0.119^{* * *} \\
(0.032)\end{array}$ \\
\hline ROA & $\begin{array}{c}0.233 \\
(0.150)\end{array}$ & $\begin{array}{c}0.806 \\
(1.614)\end{array}$ & $\begin{array}{c}0.627 \\
(2.843)\end{array}$ \\
\hline leverage & $\begin{array}{l}-0.035 \\
(0.032)\end{array}$ & $\begin{array}{l}-0.232 \\
(0.863)\end{array}$ & $\begin{array}{l}-0.106 \\
(0.075)\end{array}$ \\
\hline ProdHHI & $\begin{array}{c}0.081 * * \\
(0.038)\end{array}$ & $\begin{array}{c}0.896 \\
(1.011)\end{array}$ & $\begin{array}{c}0.800 \\
(1.376)\end{array}$ \\
\hline Volatility & $\begin{array}{c}-2.361^{* * *} \\
(0.845)\end{array}$ & $\begin{array}{l}-0.346 \\
(1.144)\end{array}$ & $\begin{array}{l}-2.221 \\
(1.947)\end{array}$ \\
\hline Loss Ratio & $\begin{array}{l}-0.021 \\
(0.042)\end{array}$ & $\begin{array}{l}-0.256 \\
(0.190)\end{array}$ & $\begin{array}{l}-0.013 \\
(0.276)\end{array}$ \\
\hline CEO Age & $\begin{array}{c}0.002 \\
(0.003)\end{array}$ & $\begin{array}{c}0.011 \\
(0.041)\end{array}$ & $\begin{array}{c}0.030 \\
(0.061)\end{array}$ \\
\hline CEO Tenure & $\begin{array}{c}0.012 \\
(0.023)\end{array}$ & $\begin{array}{c}0.022 \\
(0.056)\end{array}$ & $\begin{array}{c}0.029 * * * \\
(0.005)\end{array}$ \\
\hline Korea & $\begin{array}{c}0.389 \\
(1.953)\end{array}$ & $\begin{array}{c}0.891 \\
(1.371)\end{array}$ & $\begin{array}{c}0.467 \\
(0.448)\end{array}$ \\
\hline Korea $\times$ Firm Size & $\begin{array}{c}0.070 \\
(0.102)\end{array}$ & $\begin{array}{l}1.279 * * \\
(0.565)\end{array}$ & $\begin{array}{c}0.124 \\
(0.233)\end{array}$ \\
\hline Korea $\times$ ROA & $\begin{array}{l}-1.655 \\
(1.170)\end{array}$ & $\begin{array}{l}-0.580 \\
(0.714)\end{array}$ & $\begin{array}{l}-0.532 \\
(0.473)\end{array}$ \\
\hline Korea $\times$ Leverage & $\begin{array}{l}-2.387 \\
(1.515)\end{array}$ & $\begin{array}{l}-2.172 \\
(9.282)\end{array}$ & $\begin{array}{c}0.677 \\
(0.424)\end{array}$ \\
\hline Korea $\times$ ProdHHI & $\begin{array}{l}-0.225 \\
(0.376)\end{array}$ & $\begin{array}{c}-1.910^{* * *} \\
(0.611)\end{array}$ & $\begin{array}{l}-0.526 \\
(0.854)\end{array}$ \\
\hline Korea $\times$ Volatility & $\begin{array}{c}2.608^{* * * *} \\
(0.962)\end{array}$ & $\begin{array}{c}0.902 \\
(1.184)\end{array}$ & $\begin{array}{l}1.095 * * \\
(0.521)\end{array}$ \\
\hline Korea $\times$ Loss Ratio & $\begin{array}{c}0.027 \\
(0.723)\end{array}$ & $\begin{array}{c}0.347 \\
(0.513)\end{array}$ & $\begin{array}{c}0.219 \\
(1.640)\end{array}$ \\
\hline Korea $\times$ CEO Age & $\begin{array}{l}-0.008 \\
(0.035)\end{array}$ & $\begin{array}{l}-0.173 \\
(0.195)\end{array}$ & $\begin{array}{l}-0.019 \\
(0.027)\end{array}$ \\
\hline Korea $\times$ CEO Tenure & $\begin{array}{c}0.008 \\
(0.005)\end{array}$ & $\begin{array}{c}0.019 \\
(0.032)\end{array}$ & $\begin{array}{c}0.010 \\
(0.008)\end{array}$ \\
\hline Observations & 169 & 169 & 169 \\
\hline Hansen Test ( $p$-value) & 0.284 & 0.584 & 0.438 \\
\hline $\operatorname{AR}(1)(p$-value) & 0.000 & 0.000 & 0.000 \\
\hline $\operatorname{AR}(2)(p$-value $)$ & 0.370 & 0.426 & 0.242 \\
\hline R-squared & 0.655 & 0.643 & 0.416 \\
\hline
\end{tabular}

Note: Bootstrap standard error robust to heteroskedasticity are in parentheses. ${ }^{*},{ }^{* *},{ }^{* * *}$ significant at 10 percent, 5 percent, and 1 percent level, respectively. See Table 1 for variable definitions. 
Table 10. Comparison of Compensation-performance Sensitivity using system GMM.

\begin{tabular}{|c|c|c|c|}
\hline Dependent Variable & $\Delta$ Salary & $\Delta$ Bonus & $\Delta$ Total \\
\hline Intercept & $\begin{array}{c}3.352 * * * \\
(0512)\end{array}$ & $\begin{array}{c}16.676^{* * *} \\
(2.705)\end{array}$ & $\begin{array}{c}2.557^{* *} \\
(1.190)\end{array}$ \\
\hline$\Delta$ Salaryt-1 & $\begin{array}{c}0.511^{* * *} \\
(0.067)\end{array}$ & & \\
\hline$\Delta$ Bonust-1 & & $\begin{array}{c}0.298^{* *} \\
(0.142)\end{array}$ & \\
\hline$\Delta$ Totalt-1 & & & $\begin{array}{c}0.317^{* * *} \\
(0.072)\end{array}$ \\
\hline Korea & $\begin{array}{c}-0.384^{* * *} \\
(0.116)\end{array}$ & $\begin{array}{l}-3.755 \\
(2.871)\end{array}$ & $\begin{array}{c}-1.883^{* * *} \\
(0.381)\end{array}$ \\
\hline$\Delta S W$ & $\begin{array}{c}0.002 \\
(0.003)\end{array}$ & $\begin{array}{c}0.395^{* * *} \\
(0.072)\end{array}$ & $\begin{array}{c}0.011 \\
(0.012)\end{array}$ \\
\hline Korea $\times \Delta \mathrm{SW}$ & $\begin{array}{l}-0.008 \\
(0.019)\end{array}$ & $\begin{array}{c}-0.041^{* * *} \\
(0.008)\end{array}$ & $\begin{array}{l}-0.002 \\
(0.006)\end{array}$ \\
\hline Firm Size & $\begin{array}{l}0.029 * \\
(0.016)\end{array}$ & $\begin{array}{c}0.889 * * \\
(0.434)\end{array}$ & $\begin{array}{c}0.220 * * * \\
(0.052)\end{array}$ \\
\hline $\mathrm{ROA}$ & $\begin{array}{l}1.403 \text { ** } \\
(0.549)\end{array}$ & $\begin{array}{l}1.981 * * \\
(0.944)\end{array}$ & $\begin{array}{c}1.862 \\
(1.763)\end{array}$ \\
\hline leverage & $\begin{array}{c}-0.056 \\
(0.042)\end{array}$ & $\begin{array}{c}-0.566^{* * *} \\
(0.078)\end{array}$ & $\begin{array}{l}-0.139 \\
(0.135)\end{array}$ \\
\hline ProdHHI & $\begin{array}{c}0.033 \\
(0.075)\end{array}$ & $\begin{array}{c}0.363 \\
(1.027)\end{array}$ & $\begin{array}{c}0.268 \\
(0.243)\end{array}$ \\
\hline Volatility & $\begin{array}{l}-0.064 \\
(0.415)\end{array}$ & $\begin{array}{c}-0.400^{* * *} \\
(0.082)\end{array}$ & $\begin{array}{l}-1.141 \\
(1.340)\end{array}$ \\
\hline Loss Ratio & $\begin{array}{c}-0.395^{* *} \\
(0.173)\end{array}$ & $\begin{array}{c}-0.542^{* * *} \\
(0.109)\end{array}$ & $\begin{array}{c}-0.175 \\
(0.558)\end{array}$ \\
\hline CEO Age & $\begin{array}{c}0.004 \\
(0.003)\end{array}$ & $\begin{array}{c}0.012 \\
(0.015)\end{array}$ & $\begin{array}{c}0.006 \\
(0.010)\end{array}$ \\
\hline CEO Tenure & $\begin{array}{l}0.007 * * \\
(0.003)\end{array}$ & $\begin{array}{c}0.006 \\
(0.005)\end{array}$ & $\begin{array}{c}0.009 \\
(0.006) \\
\end{array}$ \\
\hline Observations & 169 & 169 & 169 \\
\hline Hansen Test ( $p$-value) & 0.675 & 0.578 & 0.613 \\
\hline $\operatorname{AR}(1)(p$-value $)$ & 0.000 & 0.000 & 0.000 \\
\hline $\operatorname{AR}(2)(p$-value) & 0.314 & 0.328 & 0.361 \\
\hline R-squared & 0.587 & 0.645 & 0.579 \\
\hline
\end{tabular}

5 percent, and 1 percent level, respectively. See Table 1 for variable definitions.

\section{Conclusions}

Using publicly available data on CEO compensation, we performed a study of the level, structure, and pay-performance relationship in Korean non-life insurance firms. Our evidence shows that firm characteristics and CEO-specific attributes play an important role in setting CEO compensation in Korean non-life insurance firms. We also found that performance-based pay is positively associated with a firm's financial profitability and value in Korean non-life insurance companies. Furthermore, we have provided evidence for significant differences in level, structure, and pay-performance relationship between Korean non-life firms and US property-liability insurance firms. Our results indicate that it is necessary to tie performance-based compensation more closely to shareholder value in Korean non-life insurers. Our evidence is consistent with Pan and Zhou (2018) and Lee and $\mathrm{Wu}(2020)$ suggesting that a global trend toward US-style compensation scheme does not apply to Asian countries, such as Korea and Japan. Our findings provide new evidence on international executive pay differentials by demonstrating that despite an international trend towards a US-style CEO compensation system, the executive compensation system of Korean non-life insurers has maintained its distinct features and remains significantly different from that of US property-liability insurers. Taken together, our results provide 
important implications in developing efficient $\mathrm{CEO}$ compensation arrangements in the Korean non-life insurance industry.

The limitations of our study and future research must also be discussed. First, the limitation of our study is that we used a small sample of eight publicly traded Korean non-life insurance firms in a relatively short period of time. Therefore, further research may need to extend our study based on a larger sample and an extended period of time in the future. With regard to future research, since this research mainly focuses on the comparison between Korean and US insurers, we call for future study testing for differences between Korean insurers and non-US countries' insurers if data is available.

Author Contributions: Methodology, H.M.; Writing—original draft, S.H.; Writing, Review \& editing, S.H. and H.M. All authors have read and agreed to the published version of the manuscript.

Funding: This research received no external funding.

Conflicts of Interest: The authors declare no conflict of interest.

\section{Notes}

1 IFRS 17 is an international financial reporting standard, which was announced by the International Accounting Standards Board (IASB) in 2017. K-ICS is the local statutory insurance accounting standards that was issued by Korea's Financial Supervisory Commission (FSC) in 2018. The purpose of IFRS 17 and K-ICS is to improve financial soundness of Korean insurance companies.

2 Lee and $\mathrm{Wu}$ (2020) find that there are some differences between the Korean and US systems of CEO compensation. They compare executive remuneration of public Korean firms and US Firms. However, we explore the determinants of CEO compensation of Korean insurers and also investigate the underlying channel explaining the difference between Korean non-life insurers and US property-liability insurers.

3 DART is an acronym for Data Analysis, Retrieval and Transfer System, and EDGAR stands for Electronic Data Gathering, Analysis, and Retrieval system.

4 Although our sample consists of 8 Korean publicly traded non-life insurance companies over the period 2013-2018, for some Korean non-life insurance companies, there were years when their CEO compensation is less than 5 Million Won and thus, we could not obtain data on CEO compensation for that year. In addition, KB Insurance Co., Ltd. was delisted in 2017. This is the reason why we have unbalanced panel data with 33 firm-year observations instead of 48 .

5 We conduct a Hausman test of the null hypothesis that the firm-specific error term is uncorrelated with the residuals to determine which model to use between fixed effects or random effects. The Hausman test rejects the null hypothesis for all the estimations, suggesting that the fixed effects model fits the data better.

6 Total compensation is the sum of salary, annual bonus, and other payments for Korean non-life insurers. For US publicly traded property-liability insurers, it is calculated as the sum of salary, annual bonus, value of options granted, restricted stock grants, long-term incentive plan (LTIP) payouts, and all other compensation.

7 The product lines included in the calculation of Herfindahl index of Korean non-life insurers are the following eight lines: fire, marine, automobile, engineering, liability, casualty, multiple peril, and long-term care.

8 Since stock-based pay is not used in Korean non-life insurance firms, we cannot conduct an analysis of the comparison of pay-performance sensitivity for long-term incentives, such as stock options and restricted stocks.

\section{References}

Alves, Paulo, Eduardo Barbosa Couto, and Paulo Morais Francisco. 2016. Executive Pay and Performance in Portuguese Lsted Companies. Research in International Business and Finance 37: 184-95. [CrossRef]

Basu, Sudipta, Lee-Seok Hwang, Toshiaki Mitsudome, and Joseph Weintrop. 2007. Corporate Governance, Top Executive Compensation and Firm Performance in Japan. Pacific-Basin Finance Journal 15: 56-79. [CrossRef]

Bebchuk, Lucian A., Jesse Fried, and David Walker. 2002. Managerial Power and Rent Extraction in the Design of Executive Compensation. University of Chicago Law Review 69: 751-846. [CrossRef]

Beck, Daniel, Gunther Friedl, and Peter Schäfer. 2020. Executive Compensation in Germany. Journal of Business Economics 90: 787-824. [CrossRef]

Bender, Ruth. 2003. How Executive Directors' Remuneration is Determined in Two FTSE 350 Utilities. Corporate Governance 11: 206-17. [CrossRef]

Bertrand, Marianne. 2009. CEOs. Annual Review of Economics 1: 121-50. [CrossRef]

Blanes, Fabián, Cristina de Fuentes, and Rubén Porcuna. 2020. Executive Remuneration Determinants: New Evidence from MetaAnalysis. Economic Research-Ekonomska istraživanja 33: 1-23. [CrossRef] 
Blundell, Richard, and Stephen Bond. 1998. Initial Conditions and Moment Restrictions in Dynamic Panel Data Models. Journal of Econometrics 87: 115-43. [CrossRef]

Carson, James M., and Robert E. Hoyt. 1995. Life Insurer Financial Distress: Classification Models and Empirical Evidence. Journal of Risk and Insurance 62: 764-75. [CrossRef]

Choi, Wooseok, Sam Han, Sung Hwan Jung, and Tony Kang. 2015. CEO's Operating Ability and the Association between Accruals and Future Cash Flows. Journal of Business Finance and Accounting 42: 619-34. [CrossRef]

Conyon, Martin J., John E. Core, and Wayne R. Guay. 2011. Are US CEOs Paid More Than UK CEOs? Inferences from Risk-Adjusted Pay. The Review of Financial Studies 24: 402-38. [CrossRef]

Conyon, Martin J., and Kevin J. Murphy. 2000. The Prince and the Pauper? CEO Pay in the United States and United Kingdom. The Economic Journal 110: 640-71. [CrossRef]

Conyon, Martin J., Nuno Fernandes, Miguel A. Ferreira, Pedro Matos, and Kevin J. Murphy. 2013. The Executive Compensation Controversy: A Transatlantic Analysis. In Productivity, Profits and Pay, Part 1. Edited by T. Boeri, C. Lucifora and K. J. Murphy. Oxford: Oxford University Press.

Cordeiro, James J., and Rajaram Veliyath. 2003. Beyond Pay for Performance: A Panel Study of the Determinants of CEO Compensation. American Business Review 21: 56-66.

Core, John E., Robert W. Holthausen, and David F. Larcker. 1999. Corporate Governance, Chief Executive Officer Compensation, and Firm Performance. Journal of Financial Economics 51: 371-406. [CrossRef]

Craighead, Jane A., Michel L. Magnan, and Linda Thorne. 2004. The Impact of Mandated Disclosure on Performance-Based CEO Compensation. Contemporary Accounting Research 21: 369-98. [CrossRef]

Darrough, Masako N., and Nahum D. Melumad. 1995. Divisional versus Company-wide Focus: The Trade-off between Allocation of Managerial Attention and Screening of Talent. Journal of Accounting Research 33: 65-94. [CrossRef]

de Andrés, Pablo, and Laura Arranz-Aperte. 2019. Are European CEOs paid equally? A Study of the UK-Continental Europe Pay Gap. Finance Research Letters 29: 169-77. [CrossRef]

Eckles, David L., Martin Halek, Enya He, David W. Sommer, and Rongrong Zhang. 2011. Earnings Smoothing, Executive Compensation, and Corporate Governance: Evidence from the Property-Liability Insurance Industry. Journal of Risk and Insurance 78: 761-90. [CrossRef]

Fernandes, Nuno, Miguel A. Ferreira, Pedro Matos, and Kevin J. Murphy. 2013. Are U.S. CEOs Paid More? New International Evidence. Review of Financial Studies 26: 323-67. [CrossRef]

Finkelstein, Lisa M., Kelly D. Higgins, and Maggie Clancy. 2000. Justifications for Ratings of Old and Young Job Applicants: An Exploratory Content Analysis. Experimental Aging Research 26: 263-83.

Firth, Michael, Peter M.Y. Fung, and Oliver M. Rui. 2006. Corporate Performance and CEO Compensation in China. Journal of Corporate Finance 12: 693-714. [CrossRef]

Frydman, Carola, and Raven E. Saks. 2010. Executive Compensation: A New View from a Long Perspective, 1936-2005. Review of Financial Studies 23: 2099-138. [CrossRef]

Garvey, Gerald T., and Todd T. Milbourn. 2003. Incentive Compensation when Executives can Hedge the Market: Evidence of Relative Performance Evaluation in the Cross Section. The Journal of Finance 58: 1557-82. [CrossRef]

Greene, William H. 2011. Econometric Analysis, 7th ed. Englewood Cliffs: Prentice Hall.

Hall, Brian J., and Jeffrey B. Liebman. 1998. Are CEOs Really Paid Like Bureaucrats? Quarterly Journal of Economics 113: 653-91. [CrossRef]

Hall, Brian J., and Kevin J. Murphy. 2002. Stock Options for Undiversified Executives. Journal of Accounting and Economics 33: 3-42. [CrossRef]

Hill, Charles WL, and Phillip Phan. 1991. CEO Tenure as a Determinant of CEO Pay. The Academy of Management Journal 34: 707-17.

Holmström, Bengt. 1979. Moral hazard and Observability. The Bell Journal of Economics 10: 74-91. [CrossRef]

Holmström, Bengt, and Paul Milgrom. 1987. Aggregation and Linearity in the Provision of Intertemporal Incentives. Econometrica 55: 303-28. [CrossRef]

Houston, Joel F., and Christopher James. 1995. CEO Compensation and Bank Risk: Is Compensation in Banking Structured to Promote Risk Taking? Journal of Monetary Economics 36: 405-31. [CrossRef]

Jensen, Michael C., and Kevin J. Murphy. 1990. Performance Pay and Top-Management Incentives. The Journal of Political Economy 98: 225-64. [CrossRef]

Jensen, Michael C., Kevin J. Murphy, and Eric G. Wruck. 2004. Remuneration: Where We've Been, How We Got to Here, What the Problems, and How to Fix Them. Working Paper. Cambridge: Harvard University.

Jensen, Michael C., and William H. Meckling. 1976. Theory of the Firm: Managerial Behavior, Agency Costs and Ownership Structure. Journal of Financial Economics 3: 305-60. [CrossRef]

Kato, Hideaki Kiyoshi, Michael Lemmon, Mi Luo, and James Schallheim. 2005. An Empirical Examination of the Costs and Benefits of Executive Stock Options: Evidence from Japan. Journal of Financial Economics 78: 435-61. [CrossRef]

Kaya, Emine Öner. 2015. The Effects of Firm-Specific Factors on the Profitability of Non-Life Insurance Companies in Turkey. International Journal of Financial Studies 3: 510-29. [CrossRef]

Khan, Walayet A., and João Paulo Vieito. 2013. CEO Gender and Firm Performance. Journal of Economics and Business 67: 55-66. [CrossRef] 
Kleffner, Anne E., and Neil A. Doherty. 1996. Costly Risk Bearing and the Supply of Catastrophic Insurance. Journal of Risk and Insurance 63: 657-71. [CrossRef]

Kuo, Chii-Shyan, Ming-Yuan Leon Li, and Shang-En Yu. 2013. Non-uniform Effects of CEO Equity-based Compensation on Firm Performance-An Application of a Panel Threshold Regression Model. The British Accounting Review 45: 203-14. [CrossRef]

Lambert, Richard A., and David F. Larcker. 1987. An Analysis of the Use of Accounting and Market Measures of Performance in Executive Compensation Contracts. Journal of Accounting Research 25: 85-125. [CrossRef]

Lee, Changmin, and Lingyu Wu. 2020. A Comparison of CEO Pay-Korean Listed Firms and U.S. Listed Firms. Applied Economics Letters, 1-4. [CrossRef]

Lippert, Robert L., and Gayle Porter. 1997. Understanding CEO Pay: A Test of Two Pay to Performance Sensitivity Measures with Alternative Measures of Alignment and Influence. Journal of Business Research 40: 127-38. [CrossRef]

Lippert, Robert L., and William T. Moore. 1994. Compensation Contracts of Chief Executive Officers: Determinants of Pay-Performance Sensitivity. Journal of Financial Research 3: 321-32. [CrossRef]

Malik, Hifza. 2011. Determinants of Insurance Companies Profitability: An Analysis of Insurance Sector of Pakistan. Academic Research International 1: 315-32.

Mayers, David, and Clifford W. Smith Jr. 1990. On the Corporate Demand for Insurance: Evidence from the Reinsurance Market. Journal of Business 63: 19-40. [CrossRef]

Ma, Yu-Luen, and Ping Wang. 2014. Executive Compensation and Risk Taking in the Property and Liability Insurance Industry. Journal of Insurance Issues 37: 187-207.

Merhebi, Rachel, Kerry Pattenden, Peter L. Swan, and Xianming Zhou. 2006. Australian Chief Executive Officer Remuneration: Pay and Performance. Accounting and Finance 46: 481-97. [CrossRef]

Murphy, Kevin J. 1985. Corporate Performance and Managerial Remuneration: An Empirical Analysis. Journal of Accounting and Economics 7: 11-42. [CrossRef]

Oldfield, George S., and Anthony M. Santomero. 1997. Risk Management in Financial Institutions. Sloan Management Review 39: 33-46.

Opler, Tim, and Sheridan Titman. 1993. The Determinants of Leveraged Buyout Activity: Free Cash Flow vs. Financial Distress Costs. Journal of Finance 48: 1985-99. [CrossRef]

Ozkan, Neslihan. 2011. CEO Compensation and Firm Performance: An Empirical Investigation of UK Panel Data. European Financial Management 7: 260-85. [CrossRef]

Pan, Luyao, and Xianming Zhou. 2018. CEO Compensation in Japan: Why So Different from the United States? Journal of Financial and Quantitative Analysis 53: 2261-92. [CrossRef]

Rose, Nancy L., and Andrea Shepard. 1997. Firm Diversification and CEO Compensation: Managerial Ability or Executive Entrenchment? The RAND Journal of Economics 28: 489-514. [CrossRef]

Schmidt, Dennis R., and Karen L. Fowler. 1990. Post-Acquisition Financial Performance and Executive Compensation. Strategic Management Journal 11: 559-69. [CrossRef]

Shim, Jeungbo. 2011. Merger \& Acquisitions, Diversification and Performance in the US Property Liability Insurance Industry. Journal of Financial Services Research 39: 119-44.

Smith, Clifford W., and Rene M. Stulz. 1985. The Determinants of Firms' Hedging Policies. Journal of Financial and Quantitative Analysis 204: 391-405. [CrossRef]

Stulz, René M. 1996. Rethinking Risk Management. Journal of Applied Corporate Finance 9: 8-24. [CrossRef]

Tosi, Henry L., Steve Werner, Jeffrey P. Katz, and Luis R. Gomez-Mejia. 2000. How Much does Performance Matter? A Meta-Analysis of CEO Pay Studies. Journal of Management 26: 301-39. [CrossRef]

Perrin, Towers. 2006. Managing Global Pay and Benefits: Worldwide Total Remuneration 2005-2006. Available online: www. towersperrin.com (accessed on 15 October 2021).

Van Essen, Marc, Jordan Otten, and Edward J. Carberry. 2015. Assessing managerial power theory: A Meta-analytic Approach to Understanding the Determinants of CEO Compensation. Journal of Management 41: 164-202. [CrossRef]

Willis Towers Watson Article. 2020. CEO Pay Landscape in Japan, the U.S. and Europe-2020 Analysis. Available online: https:/ /www. willistowerswatson.com/en-US/Insights/2020/12/ceo-pay-landscape-in-japan-the-us-and-europe-2020-analysis (accessed on 15 October 2021).

Wooldridge, Jeffrey M. 2002. Econometric Analysis of Cross Section and Panel Data. Cambridge: MIT Press.

Yang, Yu-Hsiang, Yao-Min Chiang, Hai-Ming Liu, and Li Huang. 2021. Negotiating or Regulating Executive Compensation: Application of Benford's Law. Applied Economics Letters, 1-5. [CrossRef] 